\title{
2-hydroxyethyl methacrylate composite - polypropylene mesh for preventing peritoneal adhesions in female dogs ${ }^{1}$
}

\author{
Compósito 2-hidroxietil dimetacrilato-tela de polipropileno para prevenção de aderências \\ peritoneais em cadelas
}

\author{
Marcelo Seixo de Brito e Silva ${ }^{\mathrm{I}}$, Renato Miranda de Melo ${ }^{\mathrm{II}}$, Liliana Borges de Menezes ${ }^{\mathrm{III}}$, Sonia Maria Malmonge ${ }^{\mathrm{IV}}$, Leandro \\ Guimarães FrancoI, Neusa Margarida Paulov \\ I Fellow PhD degree, Post-graduate Program in Animal Science, School of Veterinary, UFG, Goiás-GO, Brazil. \\ ${ }^{\text {II }} \mathrm{PhD}$, Associate Professor of Surgery, School of Medicine, UFG, Goiás-GO, Brazil. \\ III PhD, Associate Professor, General Pathology, Department of Microbiology, Immunology, Parasitology and Pathology, UFG, Goiás-GO, Brazil. \\ ${ }^{\text {IV }} \mathrm{PhD}$, Associate Professor, Chemical Engineering, Center of Engineering, Modeling and Socials Applieds Sciences, Federal University of ABC, Santo \\ André-SP, Brazil. \\ ${ }^{\vee}$ Associate Professor, Veterinary Surgery, School of Veterinary, UFG, Goiás-GO, Brazil.
}

\begin{abstract}
Purpose: To evaluate whether the lining facing the visceral side of polypropylene mesh made with 2-hydroxyethyl methacrylate (p(HEMA)) hydrogel could avoid peritoneal adhesion in female dogs. Methods: Eight animals (group PP) had a polypropylene mesh implanted to correct a defect in the rectal abdominal muscle, whereas in the other group (group PH) the polypropylene mesh was coated with p(HEMA) composite on the surface facing the peritoneal area. Results: Adhesions were observed on the mesh in 62.5\% of the PP group. In the PH group adhesions were present only on the suture lines. Conclusion: p(HEMA) hydrogel was well tolerated and effective in avoiding visceral and omental adhesions on the surface of the polypropylene mesh.
\end{abstract}

Key words: Biocompatible Materials. Hernia. Polypropylenes. Dogs.

\section{RESUMO}

Objetivo: Avaliar se o revestimento da face visceral de uma tela de polipropileno com 2-hidroxietil dimetacrilato (p(HEMA)) poderia evitar aderências peritoniais em cadelas. Métodos: Em oito animais (Grupo PP) foram implantadas telas de polipropileno para correção de um defeito do músculo reto abdominal, enquanto em outro grupo (Grupo PH) fez-se a implantação de uma tela de polipropileno cuja face peritonial foi revestida por 2-hidroxietil dimetacrilato (p(HEMA)). Resultados: Foram observados 62,5\% de aderências peritoniais sobre a tela nos animais do Grupo PP, enquanto que no Grupo PH estas não ocorreram, exceto sobre a linha se sutura. Conclusão: O hidrogel de p(HEMA) foi bem tolerado pelos animais e mostrou-se efetivo na prevenção das aderências viscerais e omentais sobre a tela de polipropileno.

Descritores: Materiais Biocompatíveis. Hernia. Polipropilenos. Cães.

${ }^{1}$ Research performed at School of Veterinary, Federal University of Goiás (UFG), Goiânia, Brazil.

\section{Introduction}

Adequate primary tension-free closure of major defects in the abdominal wall may be compromised when great losses of tissue or muscle retraction occur ${ }^{1}$. In such cases, synthetic materials may provide a steady support for the restored wall ${ }^{2}$. However, intraperitoneal implanting of synthetic material may lead to dense adhesion of visceral organs, which may result in other complications ${ }^{3}$. Despite the great progress in surgical research on adopting strategies to prevent formation of adhesion due to intra-abdominal mesh implanting, it still represents a major post-surgical issue ${ }^{4}$.
Since the first reconstruction of thoracic and abdominal walls reported by Francis C. Usher ${ }^{5}$, polypropylene mesh has been the most used biomaterial due to its relative inertia and its easiness in being anchored to the adjacent fascia. Also, it is well tolerated by the organism and completely embodied by fiber collagen tissue, it totally integrates with the surrounding newborn tissue and offers high traction resistance to the repaired area ${ }^{6,7}$. Additionally, the polypropylene mesh is resilient, easy to manipulate, and inexpensive.

Although polypropylene mesh can be incorporated into receptor tissues, it may trigger a foreign-body reaction that leads to fibrosis. This may promote the development of adhesions, 
entero-cutaneous fistula, and migration of the prosthesis, besides favoring the formation of visceral lesions during adhesiolysis ${ }^{2,4,6,8,9}$. All meshes may cause chronic inflammatory response ${ }^{10}$ with the development of granuloma and formation of capsule fibrosis, these responses depend on the extension of the lesion created during the biomaterial implanting.

Chemical composition, surface charge, porosity, roughness, size and shape of the biomaterial also influence the outcomes. Biomaterial released of residual monomers and degrading products may also interfere with host tissue response ${ }^{11}$. On the other hand, the suturing thread used to fixate the material to the wall may also be responsible for some of the complications observed. All together, these issues may lead to a lack of confidence in using biomaterials ${ }^{12}$.

Strategies to prevent adhesion by employing barrier systems have been considered, although there is no consensus on which material should be considered as ideal; whatsoever autologus barriers are difficult to obtain and require a longer surgical time ${ }^{13}$. Experimental animal models have been used to help testing new materials that may or may not suit the complexities that exist between the host tissue and the biomaterial ${ }^{14}$.

The barrier system aims to prevent contact between visceral organs and the polypropylene of the mesh, as a way to avoid adhesion formation. In an attempt to minimize, or even eliminate such formations, a number of different composites have been created to combine different materials with the polypropylene meshes ${ }^{15}$. It has been shown that adding a non-absorbable and waterproof layer over the peritoneal surface of the composite may prevent the formation of adhesion ${ }^{4}$.

The composites used nowadays have the ideal characteristics required in a biomaterial, such as increased resilience offered to the repaired area. More specifically, the side facing the peritoneum is expected to work as a physical barrier, avoiding adhesion formation. Among the many different materials being used for the mesh lining the hydrophilic polymers may be pointed out ${ }^{16}$.

As described by Hsuie et al. ${ }^{15}$, hydrogel is originaly a copolymer of etileno glycol dimethacrylate developed by Wichterle and Lim in 1954, and was the base used to make the first soft contact lenses. The synthetic polymers represented by hydrogels are made of flexible and light hydrophilic resin and have been used for the production of several devices. The hydrogel of 2-hydroxyethyl methacrylate (p(HEMA)) is a light, flexible, biocompatible, and non-toxic material which presents no antigenic activity. Thus, it has been used to develop a number of medical devices such as drug releasing systems ${ }^{17}$, tubes for conducting neural growth ${ }^{18,19}$, intra-ocular implants ${ }^{20}$, and as artificial articular surfaces $^{21,22}$.

In this study we evaluated if a 2-hydroxyethyl methacrylate ( $\mathrm{p}$ (HEMA)) hydrogel layer facing the visceral side of the polypropylene mesh would be able to avoid peritoneal adhesion formation in female dogs.

\section{Methods}

This project was approved by the Animal Ethics Committee of Research at the Federal University of Goiás, under the protocol number $054 / 2008$.

Sixteen adult female mongrel dogs, weighing between $7 \mathrm{~kg}$ and $14 \mathrm{~kg}$ were used. The animals were previously examined to detect any disease or pregnancy; blood samples were collected for blood analysis and hematozoa investigation, and then they were vaccinated and dewormed. Animals were kept in individual boxes, with free access to solarium and water, and fed with commercial dog food containing $22 \%$ gross protein twice a day.

Animals were divided in two groups of eight individuals. Group PP included animals submitted polypropylene mesh implant, whilst group PH included those submitted to p(HEMA)-mesh implant, which was composed of polypropylene synthesized by the laboratory of Engineering of Bioreations and Colloids at UNICAMP (Campinas - SP).

All animals received pre-anesthesia with intravenous Clorpromazin $2 \mathrm{mg} / \mathrm{kg}$ and intramuscular Tramadol $2 \mathrm{mg} / \mathrm{Kg}$. Anesthetic induction was done by intravenous application of Propofol $5 \mathrm{mg} / \mathrm{kg}$ and maintenance with Halotano in closed system.

Animals were submitted to right transversal laparotomy at the level of the umbilical scar. A defect of an average size of $3 \mathrm{~cm}^{2}$ was created in the abdominal wall by removing a segment of the rectal muscle of the abdomen wall and its sheaths. The greater omentum was partially removed and hemostasia done by electrocauterization and ligatures.

The correction of the abdominal wall was carried out with the selected mesh according to the group and anchored to wound boundaries with polypropyleno 2-0 in a continuous pattern suture. In group $\mathrm{PH}$ the side lined with the hydrogel remained facing the peritoneal cavity. Subcutaneous tissue and skin were sutured separately over the mesh, in both groups.

After surgery, dogs were kept with Elizabethan collar in individual cages. Tramadol $0.1 \mathrm{mg} / \mathrm{kg}$ was administered subcutaneously twice a day for 3 days, and Cephalexin $30 \mathrm{mg} / \mathrm{kg}$ was given orally twice a day for 10 days.

There was a video laparoscopic evaluation to investigate the presence of adhesion over the mesh 20 days after the implanting. A rigid endoscopy probe with optics of $10 \mathrm{~mm}$ diameter $(\varnothing)$ with 30 degrees angle attached to a microcamera (Storz ${ }^{\circledR}$, Tuttlingen, Germany) was used on the evaluation.

After anesthesia following the same protocol of the implanting (as above), animals were placed in dorsal decubitus with their pelvic members extending and the body slightly tending towards the right side. Captured images were processed and transferred to a video monitor (Storz ${ }^{\circledR}$, Tuttlingen, Germany), which enabled a visual exploration of the abdominal wall and the organs inside the abdominal cavity.

The criteria adopted to classify the adhesions are listed in Table 1 (adapted from Greca et al. ${ }^{23}$ ). 
TABLE 1 - Criteria used to classify the adhesions found in female dogs having undergone correction of a defective abdominal wall with polypropylene mesh and a composite of polypropylene-p(HEMA)

\begin{tabular}{cc}
\hline Criteria-based classification & Score \\
\hline No adhesion over the implant or in the suture zone & 1 \\
\hline $\begin{array}{c}\text { Adhesion of remaining omentum only in the suturing area } \\
\text { Adhesion of remaining omentum in more than } 50 \% \text { of the } \\
\text { material surface } \\
\text { Adhesion of omentum in less than } 50 \% \text { of the material } \\
\text { surface }\end{array}$ & 3 \\
Visceral adhesion only in the suturing area \\
Visceral adhesion on the material surface
\end{tabular}

Adhesions of the remaining omentum, of the viscera over the mesh, or in the suturing area were undone with tweezers and a $5 \mathrm{~mm}$ tube, which together reached the abdominal cavity through the alba line between the caudal abdominal glands. After evaluation with videolaparoscopy, dogs were ovary hysterectomized and given to donation after recovering from surgery.

Treatments were statistically compared using the UWilcoxon-Mann-Whitney (WMW) with $(p<0.05)$ for the nonparametric variables and descriptive analysis to show difference among samples, using SAEG and XLSTAT 2008 packages.

\section{Results}

The removal of an aponeurotic-muscle fragment from the abdominal rectus muscle after its transversal sectioning produced a proper parietal defect, square at first, but becoming round due to tissue retraction. There were no technical difficulties during the implantation of the mesh in both groups. The composite had a rough non-coated surface, whereas the opposite side was smooth and bright, which allowed the coated side to be implanted facing the peritoneal cavity. The mesh was cut according to the dimensions of the produced defect, neither unraveling nor spliting its layers apart.

The material proved to be resilient to the needle and it was well adapted to the rims of the defect. It presented a tendency to bulge over the lined side but without compromising it's implanting (Figure 1).
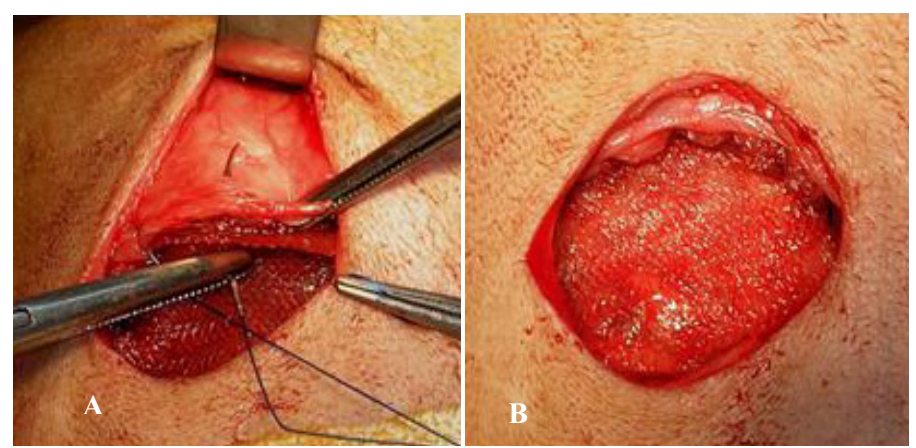

FIGURE 1 - (A) Implanting of the lined mesh for correcting the defect in the abdominal wall. (B) Final aspect after implanting the material on the abdominal wall
There were no deaths or changes in the wounds suggestive of tissue rejection of the implant, in any animal in either group. Animals walked adequately and were fed with no restriction 8 hours post-surgery and presented regular evacuation and normal feces. No animals showed signs suggestive of infection of the surgical wound. During the period of the study, abdominal palpation did not seem to cause discomfort to the animals.

After videolaparoscopic evaluation adhesions were classified according to the criteria shown in Table 1, and were grouped in Figure 2.

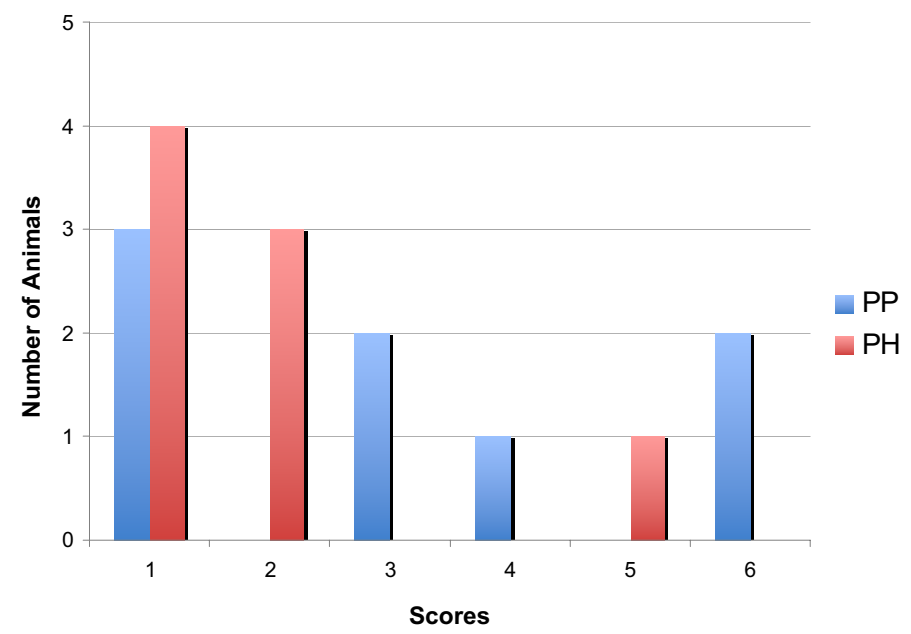

FIGURE 2 - Frequency of adhesion scores in the group with polypropylene (PP) and with composite of polypropylene- $\mathrm{p}$ (HEMA) mesh $(\mathrm{PH})$

In group PP adhesions were observed upon the mesh in five animals $(62.5 \%)$, two of which involved the intestinal rings. Adhesions were not observe on the lined material of the mesh in group PH (Figure 3A). One animal in this group presented visceral adhesion on the suture zone (12.5\%) (Figure 3B) and in three animals $(37.5 \%)$ the remaining omentum adhered to the suture zone (Figure 3C). These were loose adhesions that were easily removed. We also noticed that the peritoneal liquid and the parietal peritoneum had a normal aspect with no indication of cyst formation on the material. 

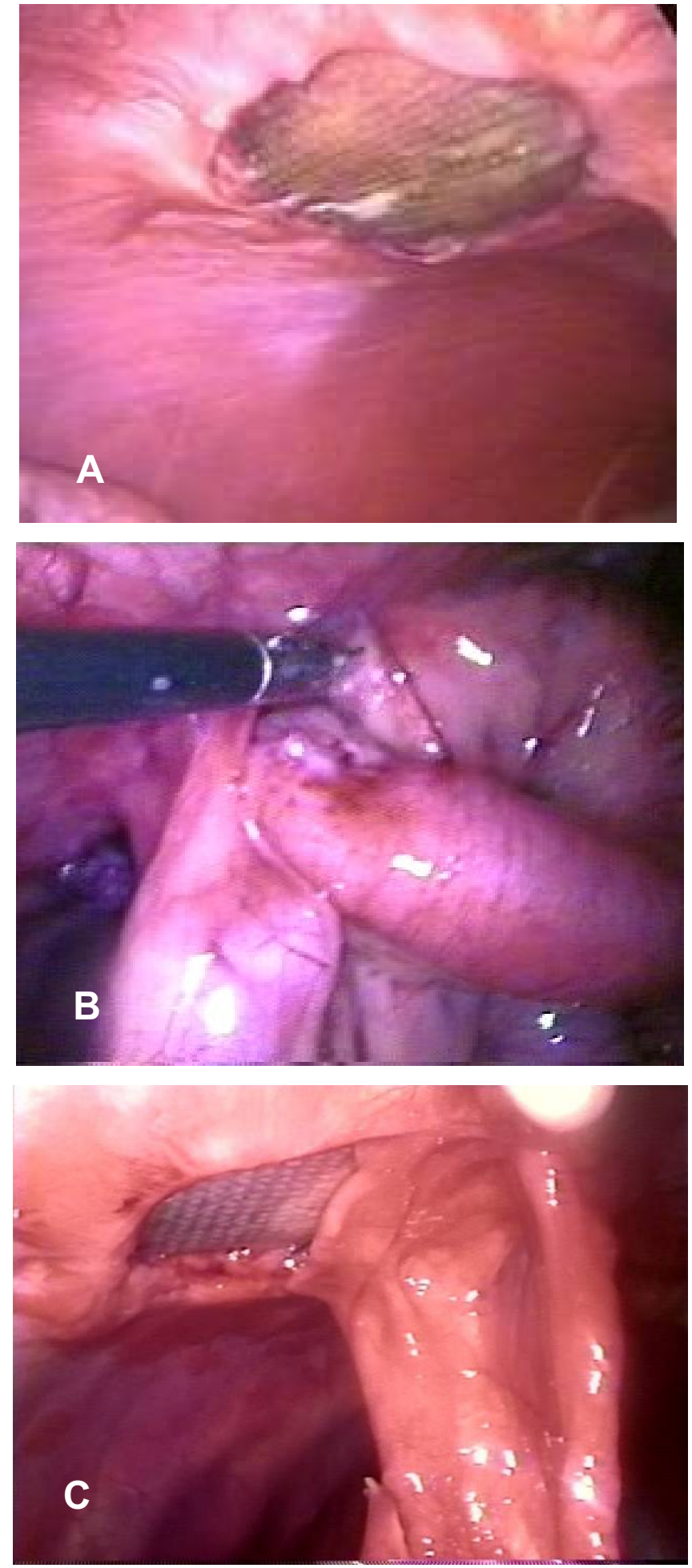

FIGURE 3 - (A) No adhesion on the polypropylene-pHEMA mesh. (B) Intestinal adhesion to the suture zone submitted to adhesiolysis. (C) Omentum adhesion in the suturing zone

\section{Discussion}

Ideally, defects of the abdominal wall should be repaired by joining the tissue's borders. However, in lack of tissue, the implanting of a synthetic prosthesis may be required to securely hold the closure. Despite its potential to cause intestinal adhesions, polypropylene mesh is the material most commonly used in these cases $^{26}$.
The presence of an inflammation exsudate and formation of a fibrous matrix during the first days of cicatrization are the precursors of adhesion. The presence of the polypropylene mesh may facilitate the formation of a fibrous matrix on its surface ${ }^{1,3,7}$. The adhesion of the bowel to the biomaterial is the first phase of bowel fistulization, which is considered more severe than the adhesions of the omentum ${ }^{6}$. The adhesions observed on the mesh surface in animals from group PP worked as a response to the direct contact of the mesh and the visceral peritoneum when the $\mathrm{p}(\mathrm{HEMA})$ barrier was absent.

Omentum adhesions to the suturing zone may be caused by a greater inflammation reaction triggered by the suturing thread used to anchor the biomaterial ${ }^{12}$, which acts like a foreign body. It has been suggested that the structure and porosity of the biomaterial may play a role in this process ${ }^{2,7}$. Adhesions tend to first form on the interface of the abdominal wall and on the outer border of the mesh. Applying a suture in continuous pattern may not reduce the incidence of adhesions, when compared to separated sutures ${ }^{26}$.

The omentum plays an important role in reducing abdominal adhesions, not only because it works as a barrier between the injured wall and the viscera but also due to the production of fibrinolytic factors by the mesothelial cells, thus, its removal should be minimized ${ }^{27}$. With this in mind, for this study omentectomy procedure was chosen to increase the peritoneal challenge and to have the chance to observe the performance of the biomaterial under the most favorable conditions for the formation of adhesions.

Evaluation of experimentally induced adhesions by videolaparoscopy is considered to be a more effective method than necropsy, as it allows the abdominal changes to be magnified ${ }^{26}$. For female dogs, the paramedian access for 30-degree optical is not the usually suggested media line ${ }^{28}$, but it allowed a better view of the region where the mesh was implanted in the abdominal wall.

The complex relationship between biomaterials and tissues has been investigated by using experimental animal models. With the progress of materials sciences, tissue engineering, and multidisciplinary approaches, it has been possible to design and characterize a number of different materials for specific medical needs.

The hydrogels belong to a class of materials that can be made through several methods, which may determine the properties of the product and direct its applications. They are defined as tridimensional nets made of polymeric chains that swell but do not dissolve ${ }^{29}$. This characteristic can be checked when the material is in stock or even sterilized, as the material is still complete and tumid after autoclave sterilization.

Non biodegradable biocompatible hydrogels could reduce the formation of healing tissue, creating a favorable environment for cellular growth. This property has been investigated, and it has been suggested that this material may be used to create certain implanting devices ${ }^{15,17,27}$. Additionally, p(HEMA) hydrogel does not induce necrosis, tumors or infections but, rather, it is well tolerated, non-toxic, and biocompatible, although it may lead to the formation of a capsule most likely to represent a reaction to the foreign body ${ }^{28}$. In this study, macroscopic analysis revealed no adverse reaction to the implant in any of the animals, supporting the idea that $\mathrm{p}$ (HEMA) is indeed well tolerated.

A disadvantage of the polypropylene mesh-p(HEMA) composite is its stiffness. Nevertheless, this characteristic did not affect the implanting of the material or the behavior observed in 
animals during the post-operative period, and the implanting region could not be palpated anymore. The malleability of polypropylene mesh is considered one of the main advantages of the material, making it suitable for repairing defects of the abdominal wall ${ }^{24,25}$.

\section{Conclusion}

The 2-hydroxyethyl methacrylate $\mathrm{p}($ HEMA) hydrogel is well tolerated when used as a coating agent of polypropylene mesh, and is effective in avoiding the formation of visceral and omental adhesions on the surface of the mesh.

\section{References}

1. Genevieve M, Boland BA, Ronald J, Weigel LMD. Formation and prevention of postoperative abdominal adhesions. J Surg Res. 2006;132:3-12.

2. Felemovicius I, Bonsack ME, Hagerman G, Delaney JP. Prevention of adhesions to polypropylene mesh. J Am Coll Surg. 2004;198:543-8.

3. Costa RG, Lontra MB, Scalco P, Cavazzola LT, Gurski RR. Polylactic acid film versus acellular porcine small intestinal submucosa mesh in peritoneal adhesion formation in rats. Acta Cir Bras. 2009;24:128-35.

4. Losanoff JE, Richman BW, Jones JW. Entero-colocutaneus fistula: a late consequence of polypropylene mesh abdominal wall repair: case report and review of the literature. Hernia. 2002;6:144-7.

5. Goldstein H.S. Selecting the right mesh. Hernia. 2002;3:23-6.

6. de Vries Reilingh TS, van Geldere D, Langenhorst B, de Jong D, van der Wilt GJ, van Goor H, Bleichrodt RP. Repair of large midline incisional hernias with polypropylene mesh: Comparison of three operative techniques. Hernia. 2004;8:56-9.

7. Bellón JM, Garcia-Carranza A, Jurado F, Garcia-Honduvilla N, San Martin AC, Bujan J. Peritoneal regeneration after implant of a composite prosthesis in the abdominal wall. World J Surg. 2001;25:147-52.

8. Baptista ML, Bonsack ME, Delaney JP. Seprafilm reduces adhesions to polypropylene mesh. Surgery. 2000; 128: 86-92.

9. Dinsmore RC, Calton Jr WC, Harvey SB, Blaney MW. Prevention of adhesions to polypropylene mesh in a traumatized bowel model. J Am Coll Surg. 2000;19:131-6.

10. Klinge U, Klosterhalfen B, Müller M, Schumpelick V. Foreign body reaction to meshes used for the repair of abdominal wall hernias. Eur $\mathrm{J}$ Surg. 1999;165:665-73.

11. Babensee EJ, Anderson JM, Mikos AG. Host response to tissue engineered devices. Adv Drug Deliv Rev. 1998;33:111-39.

12. Amid PK, Shulman AG, Lichtenstein L, Hakakha M. Biomaterials for abdominal wall hernia surgery and principles of their applications. Langenbecks Arch Chir. 1994;379:168-71.
13. Wallwiener D, Meyer A, Bastert G. Adhesion formation of the parietal and visceral peritoneum: an explanation for controversy on the use of autologous and alloplastic barriers? Fertil Esteril. 1998;68:132-7.

14. Baquey C. Biomaterials science: prospects for the new millenium? J Mater Sci Mater Med. 1999;10(12):695-6.

15. Wheeler JC, Woods JA, Cox MJ. Evolution of hydrogel polymers as contact lens, surface coatings, dressings, and drug delivery systems. J Long-Term Eff Med Implants. 1996;6:207-17.

16. Bellón JM., Rodriguez M, Garcia-Honduvilla N, Pascual G, Buján J. Partially absorbable meshes for hernia repair offer advantages over nonabsorbable meshs. Am J Surg. 2007;194:68-74.

17. Hsiue GH, Guu JA, Cheng CC. Poly(2-hydroxyethyl methacrylate) film as a drug delivery system for pilocarpine. Biomaterials. 2001;22(13):1763-9.

18. Flynn L, Dalton PD, Shoichet MS. Fiber templating of poly (2-hydroxyethyl methacrylate) for neural tissue engineering. Biomaterials. 2003;24:4265-72.

19. Tsai EC, Dalton PD, Shoichet MS, Tator CH. Synthetic hydrogel guidance channels facilitate regeneration of adult rat brainstem motor axons after complete spinal cord transection. J Neurotraum. 2004;21:789-804.

20. Werner L, Apple DJ, Escobar-Gomez M, Ohrstro A, Crayford BB, Bianchi R, Pandey KS. Postoperative deposition of calcium on the surfaces of a hydrogel intraocular lens. Ophthalmology. 2000;107:2179-85.

21. Malmonge SM, Zavaglia CAC, Santos Jr AR, Wada MLF. Avaliação da citotoxicidade de hidrogéis de poliHEMA: um estudo in vitro. Rev Bras Eng Biom. 1999;15:49-5.

22. Bavaresco VP, Garrido LF, Batista NA, Malmonge SM, Belangero WD. Mechanical and morphological evaluation of osteochondral implants in dogs. J Artif Organs. 2008;32:310-6.

23. Greca FH, Paula JB, Biondo-Simões MLP, Costa FD, Silva APG, Timo A, Mansur A. The influence of differing pore sizes on the biocompatibility of two polypropylene meshes in the repair of abdominal defects. Hernia. 2001;5:59-64.

24. Baptista LM, Bonsack ME, Felemovicius I, Delaney JP. Abdominal adhesions to prosthetic mesh evaluated by laparoscopy and electron microscopy. J Am Coll Surg. 2000;190:271-80.

25. Cerci C, Eroglu E, Sutcu R, Celikbas B, Kilbas A. Effects of omentectomy on the peritoneal fibrinolytic system. Surg Today. 2008;38:711-5.

26. Kopecek J. Swel gels. Nature. 2002;417:388-91.

27. Lesný P, De Croos J, Prádný M, Vasik J, Michálek J, Woerly S, Syková E. Polymer hydrogels usable for nervous tissue repair. J Chem Neuroanat. 2002;23:243-7.

28. Izak AM, Werner L, Pandey SK, Apple DJ. Calcification of modern foldable hydrogel intraocular lens designs. Eyes. 2003;17:393-406.

29. Buchen SY, Cunanan CM, Gwon A, Weinschenk III JI, Gruber L, Knight PM. Assessing intraocular lens calcification in an animal model. J Cataract Refract Surg. 2001;27:1473-84.

\section{Correspondence:}

Conflict of interest: none

Neusa Margarida Paulo

Financial source: $\mathrm{CNPq}$

Universidade Federal de Goiás, Escola de Veterinária

Departamento de Medicina Veterinária

74001-970 Goiânia - GO Brazil

nmp@,vet.ufg.br

Received: January 14, 2010

Review: March 16, 2010

Accepted: April 19, 2010

\section{How to cite this article}

Brito e Silva MS, Melo RM, Menezes LB, Malmonge SM, Franco LG, Paulo NM. 2-hydroxyethyl methacrylate composite - polypropylene mesh for preventing peritoneal adhesions in female dogs. Acta Cir Bras. [serial on the Internet] 2010 July-Aug;25(4). Available from URL: http://www.scielo.br/acb 